Pak. J. Anal. Environ. Chem. Vol. 19, No. 2 (2018) 169 - 180

\title{
Assessment of Water Quality and Heavy Metals Contamination of River Ravi in Pakistan
}

\author{
Javairia Shafi ${ }^{*}$ Zahid Sharif Mirza, Nasreen Kosour and Muhammad Zafarullah \\ Fisheries Research and Training Institute, Lahore, Pakistan. \\ *Corresponding Author Email: javairiamalik@gmail.com \\ Received 05 March 2018, Revised 15 October 2018, Accepted 20 October 2018
}

\begin{abstract}
This study was carried out to evaluate the impact of untreated urban and industrial effluents on water quality of river Ravi. Water samples were collected from 11 polluted and relatively unpolluted sites at river Ravi during low flow season and analyzed for heavy metals content and physico-chemical parameters. Dissolved oxygen fell below the recommended limit for propagation of fish and other aquatic life as the river flows through Lahore up to Balloki Headworks. Manganese and lead contents were higher than permissible limits for aquatic ecosystems at several polluted sites of the river. Highest concentration of nickel, zinc, manganese, cadmium and lead detected in river water was $20.0 \mu \mathrm{g} / \mathrm{L}, 70.0 \mu \mathrm{g} / \mathrm{L}, 190.0 \mu \mathrm{g} / \mathrm{L}, 2.0 \mu \mathrm{g} / \mathrm{L}$ and $72.0 \mu \mathrm{g} / \mathrm{L}$ respectively. Findings revealed that river water at downstream sites of wastewater carrying drains was not suitable to support fish and other aquatic life due to its very low dissolved oxygen level.
\end{abstract}

Keywords: Aquatic biota, Metal contaminants, Oxygen depletion, Urban and industrial effluents, Waste carrying drains.

\section{Introduction}

Extensive provisionary services provided by rivers are accompanied by their water quality deterioration and loss of aquatic biodiversity [1]. Discharge of untreated wastewater of industrial, urban and agricultural origin introduces more than a million types of toxic pollutants in the rivers [2]. The biological degradation of non-conservative pollutants takes place at the cost of dissolved oxygen in the receiving water bodies and can also lead to anoxic conditions [3]. Moreover, the hazardous nature of heavy metals, a form of conservative toxicants, has been well documented for aquatic organisms [4-6]. Humans have been exposed to their toxic effects [7] either through direct exposure to polluted water or consumption of fish contaminated by toxicants bioamplification in the food webs.

Pakistan is expected to be a water scarce country in future [8] with an expected water deficiency of 151 MAF in 2025. One of the major obstacles faced by the conservation practices is the level of pollution in the country's water resources. At present, majority of industrial units have been established either within or near the urban areas. More than $99 \%$ of urban and industrial effluents eventually dispose of in the natural water reservoirs without any treatment [9]. The absence of regular monitoring programmes and surface water quality standards in the country also contribute in the continuous deterioration of our aquatic ecosystems [8].

River Ravi, a transboundary river, enters Pakistan at Shakkargarh (Sialkot) and empties in River Chenab near Shorkot. Extensive pollution load that the river receives during its course of flow through Lahore has converted it into a wastewater drain particularly during low flow season. In addition to six primary drains, the river 
receives huge load of industrial effluents through Hudiara Drain and Deg Drain. Hudiara drain carries the polluted industrial water of more than 200 industries of Pakistan and India while Deg Drain water is polluted with the toxic effluents of about 150 industries of Lahore and its surroundings [10]. Each of these two drains contribute more than 500 cusec effluent to the river daily [11]. Pollution level of the river is a serious threat for aquatic life and underground water reservoirs of the region. It is, therefore, necessary to monitor the river water quality on regular basis to investigate its pollution status for designing the appropriate mitigation strategies. A clearer picture of the fluvial environment is achieved during the low flow season due to absence of dilution effects that occurs during high flow period. Current study was, therefore, based on analysis of various physico-chemical parameters and toxic heavy metals content in the riverine water during the low flow season.

\section{Materials and Methods}

A stretch of about $160 \mathrm{~km}$ of river ravi starting from Shakkargarh, Sialkot up to Balloki
Headworks was evaluated for water quality. Water samples were collected in triplicate from 11 sites at the river. The site selection was based upon the discharge points of point pollution sources in the river. Sample collection was completed during the low flow season from January, 2016 to February, 2016.

\section{Description of study area}

River Ravi receives its major share of pollution through six primary drains; Shahdara Drain, Shalimar Escape Channel Drain, Upper Chota Ravi Drain, Lower Chota Ravi Drain, Sattu Katla Drain and Cantt Drain. In addition, two tributaries i.e. Hudiara Drain and Deg Drain dispose of huge amount of untreated effluents in the river. Details of wastewater carrying primary drains/ tributaries is presented in Table 1. Sites codes used in this research paper are presented in Table 2 with the sites coordinates. Following is the brief description of the sampling sites. Fig. 1 shows map of sampling sites at river ravi.

Table 1. Primary drains/ tributaries discharging in river Ravi.

\begin{tabular}{|c|c|c|c|c|c|}
\hline $\begin{array}{l}\text { Primary drain/ } \\
\text { Tributary }\end{array}$ & $\begin{array}{c}\text { Length } \\
(\mathrm{KM})\end{array}$ & Start & Receiving Water Body & $\begin{array}{l}\text { Location of Discharge in } \\
\text { Receiving Water Body }\end{array}$ & $\begin{array}{c}\text { Daily Discharge } \\
\text { (Cusec) }\end{array}$ \\
\hline Shahdra Drain & 4.11 & $\begin{array}{l}\text { National Bank, } \\
\text { Shahdara }\end{array}$ & River Ravi & $\begin{array}{l}\text { Farukh Abad Chowk, } \\
\text { Lahore }\end{array}$ & 119.5 \\
\hline $\begin{array}{l}\text { Shalimar Escape } \\
\text { Channel Drain }\end{array}$ & 10.0 & $\begin{array}{l}\text { Wapda Colony, GT Road, } \\
\text { Lahore }\end{array}$ & River Ravi & $\begin{array}{l}\text { Village Khokhar, District } \\
\text { Lahore }\end{array}$ & 86.0 \\
\hline $\begin{array}{l}\text { Upper Chotta Ravi } \\
\text { Drain }\end{array}$ & 4.26 & China Scheme, Lahore & $\begin{array}{l}\text { River Ravi through Shad } \\
\text { Bagh sludge carrier }\end{array}$ & $\begin{array}{l}\text { Village Pamba Chugiyan, } \\
\text { District Lahore }\end{array}$ & 133.0 \\
\hline $\begin{array}{l}\text { Lower Chotta Ravi } \\
\text { Drain }\end{array}$ & 4.26 & Bagh Munshi Ladha, Lahore & River Ravi & $\begin{array}{l}\text { Sagian Bridge, } \\
\text { Lahore }\end{array}$ & 63.0 \\
\hline Sattu Katla Drain & 17.7 & $\begin{array}{l}\text { Fruit \& Vegetable Market at } \\
\text { Ferozpur Road, Lahore }\end{array}$ & Hudiara Drain & $\begin{array}{l}\text { Valencia Housing Society, } \\
\text { Lahore }\end{array}$ & 248.0 \\
\hline Cantt Drain & 15.4 & Jorey Pull (Saddar), Lahore & River Ravi & Shahpur Kanjra, Lahore & 208.9 \\
\hline Hudiara Drain & 98.6 & $\begin{array}{l}\text { District Gurdaspur India, } \\
\text { Enters in Pakistan at Village } \\
\text { Lallo, District Lahore }\end{array}$ & River Ravi & $\begin{array}{l}\text { Village Khudpur, District } \\
\text { Lahore }\end{array}$ & $>500$ \\
\hline Deg Drain & 256.0 & $\begin{array}{l}\text { Indian held Kashmir, } \\
\text { Enters in Pakistan at Jangu } \\
\text { Chak, District Narowal }\end{array}$ & River Ravi & $\begin{array}{l}\text { Shraqpur, District } \\
\text { Sheikhupura }\end{array}$ & $>500$ \\
\hline
\end{tabular}


Table 2. Description of sampling sites.

\begin{tabular}{|c|c|c|c|c|}
\hline \multirow{2}{*}{ Sampling Site } & \multirow{2}{*}{ Site Code } & \multicolumn{2}{|c|}{ Location } & \multirow{2}{*}{ Site Description/ Point Pollution Source } \\
\hline & & Longitude (E) & Latitude (N) & \\
\hline $\begin{array}{l}\text { Kot Nainan, } \\
\text { Shakkargarh }\end{array}$ & KNS & $32^{\circ} 08^{\prime} 11.6000$ & $75^{\circ} 15^{\prime} 47.7000^{\prime \prime}$ & No traceable point source in immediate vicinity \\
\hline $\begin{array}{l}\text { Kala Khatai, } \\
\text { Narang }\end{array}$ & $\mathrm{KKN}$ & $31^{\circ} 50 ’ 38.1000^{\prime \prime}$ & $74^{\circ} 33^{\prime} 11.5002^{\prime \prime}$ & $\begin{array}{l}\text { Not traceable point source in immediate } \\
\text { vicinity }\end{array}$ \\
\hline Village Khokhar & VK & $31^{\circ} 37 ' 51.9600^{\prime \prime}$ & $74^{\circ} 19^{\prime} 45.9000^{\prime \prime}$ & $\begin{array}{l}\text { Upstream site of Shalimar Escape Channel } \\
\text { Drain discharge point }\end{array}$ \\
\hline Old Ravi Bridge & ORB1 & $31^{\circ} 36 \prime 28.3200^{\prime \prime}$ & $74^{\circ} 17 ' 35.4000^{\prime \prime}$ & $\begin{array}{l}\text { Downstream site of Shalimar Escape Channel } \\
\text { Drain discharge point }\end{array}$ \\
\hline Old Ravi Bridge & ORB2 & $31^{\circ} 36 \prime 21.6600^{\prime \prime}$ & $74^{\circ} 17^{\prime} 41.2200^{\prime \prime}$ & $\begin{array}{l}\text { Downstream site of Shalimar Escape Channel } \\
\text { Drain discharge point }\end{array}$ \\
\hline Village Gopi Rai & VGR & $31^{\circ} 29^{\prime} 13.6200^{\prime \prime}$ & $74^{\circ} 11^{\prime} 06.3600^{\prime \prime}$ & Upstream Site of Cantt Drain discharge point \\
\hline Shahpur Kanjra & SPK & $31^{\circ} 28^{\prime} 05.5800^{\prime \prime}$ & $74^{\circ} 10^{\prime} 35.4600^{\prime \prime}$ & Downstream site of Cantt Drain discharge point \\
\hline Village Khudpur & VKPU & $31^{\circ} 24^{\prime} 26.2000^{\prime \prime \prime}$ & $74^{\circ} 06^{\prime} 10.1000^{\prime \prime}$ & Upstream Site of Hudiara Drain discharge point \\
\hline Village Khudpur & VKPD & $31^{\circ} 24 ' 26.2000^{\prime \prime}$ & $74^{\circ} 05^{\prime} 58.5000^{\prime \prime}$ & $\begin{array}{l}\text { Downstream site of Hudiara Drain discharge } \\
\text { point }\end{array}$ \\
\hline $\begin{array}{l}\text { Village Nano } \\
\text { Dogar, Sunder }\end{array}$ & VNDS & $31^{\circ} 22^{\prime} 01.2000^{\prime \prime}$ & $74^{\circ} 03^{\prime} 04.2000^{\prime \prime}$ & $\begin{array}{l}\text { Downstream site of Hudiara Drain and Deg } \\
\text { Drain discharge points }\end{array}$ \\
\hline Balloki Headworks & BHW & $31^{\circ} 13^{\prime} 09.9000^{\prime \prime}$ & $73^{\circ} 51^{\prime 2} 29.7600^{\prime \prime}$ & No traceable point source in immediate vicinity \\
\hline
\end{tabular}

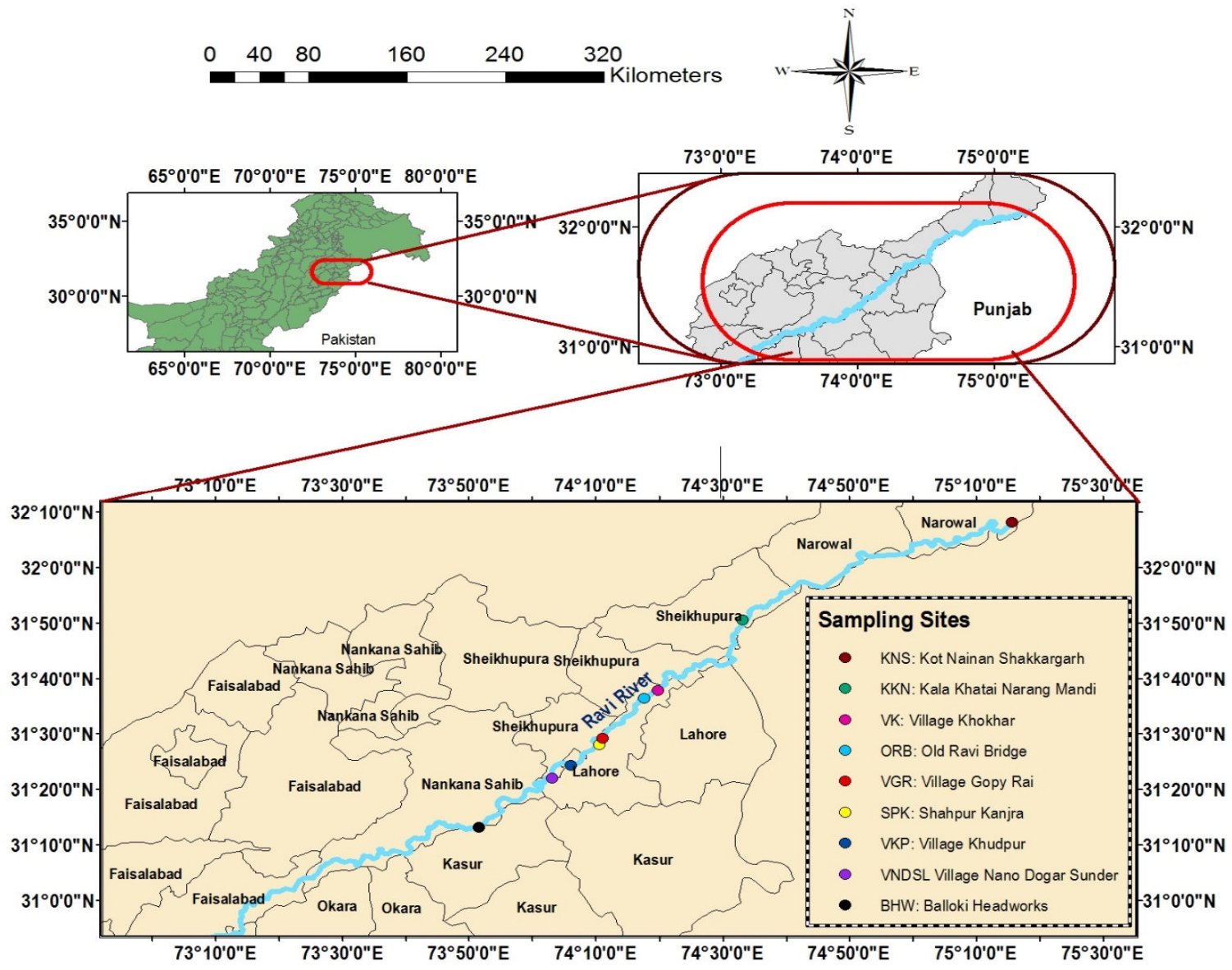

Figure 1. Map of sampling sites at river ravi 
Kot Nainan, Kala Khtai and Village Khokhar (KNS, KKN, VK)

Kot Nainan, Kala Khtai and Village Khokhar were the first three sampling sites in the present study. River Ravi enters Pakistan at Kot Nainan, Shakkargarh (KNS) and keeps flowing on either side of Indo-Pak boundary until it permanently enters in Pakistan near Ravi Siphon. Kala Khtai $(\mathrm{KKN})$ is located near Narang Mandi Town about $15 \mathrm{~km}$ upstream of Ravi Siphon. Once entered in Pakistan at Ravi Siphon, the river flows along the Kala Khatai-Narang Mandi Road up to Village Khokhar (VK). There is no identifiable point source of pollution up to Village Khokhar. Therefore, these three sample collection sites; $\mathrm{KNS}, \mathrm{KKN}$ and VK are considered as relatively unpolluted.

\section{Old Ravi Bridge (ORB 1 and ORB 2)}

Shalimar Escape Channel Drain discharges its wastewater as the river flows from Village Khokhar to old Shahdara Ravi Bridge. Two sampling sites were selected at old Ravi Bridge; ORB 1: where river water was not completely mixed with drain water and ORB 2: where river water was mainly carrying the drain's wastewater.

\section{Village Gopi Rai and Shahpur Kanjra (VGR, SPK)}

While flowing through Lahore, the river receives waste discharge of Shahdara Drain and Lower Chota Ravi Drain near New Shahdara Ravi Bridge and Sagian Bridge, respectively. Village Gopi Roy is situated near Lahore-Islamabad Motorway. A portion of Cantt drain wastewater joins an Escape Channel that emerges from Lahore Branch Canal near Thokar Niaz Beg and empties in river ravi at Shahpur Kanjra (SPK). The river at Village Gopi Rai (VGR) and Shahpur Kanjra (SPK) serves as upstream and downstream of discharge point of Cantt drain effluents in the river.

\section{Village Khudpur (VKPU and VKPD)}

Sattu Katla drain; another primary drain that originates from fruit and vegetable market at Ferozpur Road, Lahore joins the Hudiara Drain near Valencia Housing Society, Lahore. Hudiara
Drain carrying waste effluents of Sattu Katla Drain as well as the industrial effluents of India and Pakistan empties in river Ravi at Village Khudpur. Both upstream and downstream sites (VKPU and VKPD) of discharge point of Hudiara Drain in river Ravi are accessible at this site.

\section{Village Nano Dogar (VNDS)}

Village Nano Dogar (VNDS) near Sunder Industrial Estate is situated at downstream of Village Khudpur. The site serves as the downstream site of discharge point of Hudiara Drain and Deg Drain. The latter is another wastewater carrying tributary that empties in the river form the opposite side near Shraqpur.

\section{Balloki Headworks (BHW)}

There is no traceable point source of pollution at Balloki Heakworks (BHW). However, the river looks like a sewage drain at this site particularly during the low flow season due to pollution load it has received through its course of flow through Lahore. This site served as the last sampling site of the present study.

\section{Chemicals}

All chemicals used in the present work were of analytical reagent grade. Ultrapure deionized water was used for all dilutions. Nitric acid $\left(\mathrm{HNO}_{3}, \geq 65 \%\right)$ and Hydrochloric acid $(\mathrm{HCl}$, $37 \%$ ) were purchased from Sigma Aldrich, Steinheim, Germany and Lab-Scan, Bangkok, Thailand, respectively. Multi element mixed standard solutions of heavy metals were supplied by Perkin-Elmer, Norwalk, CT, USA. Hanna dissolved oxygen test kit (HI 3810, Hanna instruments, Inc., Woonsocket, RI, USA) was used for analysis of water dissolved oxygen content.

\section{Instrumentations}

Ultrapure deionized water was prepared using Siemens's water purification system (2001D/60 Ultraclear, Seimens, Germany). pH meter (Jenway, 3505, UK), conductivity meter (Crison, $\mathrm{CS}-35^{+}$, Spain) and turbidity meter (Hach, 2100AN, USA) were used for physico-chemical analysis of water samples. Perkin Elmer's ICP- 
OES (Optima 7000 DV, Perkin Elmer, Inc., Norwalk, CT, USA) was used for heavy metals analysis.

\section{Sample collection and preservation}

Water samples at each sampling site were collected from three sublocations situated at symmetrical distance from each other. Samples were collected almost $30 \mathrm{~cm}$ below the water surface from each sampling sublocation and stored in two $500 \mathrm{~mL}$ acid rinsed polyethylene bottles. The samples in one bottle were acidified with concentrated nitric acid (Sigma Aldrich) to $\mathrm{pH}<2$ immediately after collection for heavy metals analysis. Water samples collected in the second bottle were used for the determination of physicochemical parameters. Sample bottles were transported to laboratory in portable ice boxes and stored in the refrigerator at $4{ }^{\circ} \mathrm{C}$ till processing.

\section{Water analysis for physico-chemical parameters}

Temperature and dissolved oxygen (DO) of river water was determined on site. Temperature was measured by direct insertion of a laboratory thermometer in the river water at the sampling site. Water sample for dissolved oxygen analysis was collected by filling the BOD bottles with river water at a depth of about $30 \mathrm{~cm}$. Bottle was overflowed with water about three times of its volume and capped with stopper while keeping it within water to avoid entrapping of air. Dissolved oxygen was determined using dissolved oxygen test kit (Hanna, HI 3810) based on Winkler Method for oxygen determination with azide modification. Oxygen deficiency in the river water was calculated according to Boyd [12]. Conductivity, $\mathrm{pH}$ and turbidity of water samples was determined in the laboratory using electronic instruments following the standard methods [13].

\section{Water analysis for heavy metals}

All the glassware used for the preparation and storage of water samples for heavy metals analysis was rinsed with acid to prevent any contamination. Acid preserved water samples were digested using nitric acid-hydrochloric acid digestion method described in APHA [13]. Digested samples were analyzed for $\mathrm{Ni}, \mathrm{Mn}, \mathrm{Zn}$,
$\mathrm{Cd}$ and $\mathrm{Pb}$ by ICP-OES Calibration curves of metal analytes for ICP-OES analysis were prepared with working standard solutions of the metals. Multi element mixed standard solutions (Perkin Elmer) were used for the preparation of metals working standard solution. Operating conditions of ICPOES used in the present study are described in Table 3.

Table 3. Operating conditions of ICP-OES for analysis of heavy metals.

\begin{tabular}{l|ll}
\hline Detection Wavelength & $\mathrm{Cd}$ & $228.802 \mathrm{~nm}$ \\
& $\mathrm{~Pb}$ & $405.781 \mathrm{~nm}$ \\
$\mathrm{Mn}$ & $257.610 \mathrm{~nm}$ \\
& $\mathrm{Ni}$ & $231.604 \mathrm{~nm}$ \\
$\mathrm{Zn}$ & $206.200 \mathrm{~nm}$ \\
\cline { 2 - 2 } Purge gas & Nitrogen, $99.999 \%$ pure \\
Auxiliary gas flow & $0.2 \mathrm{~L} / \mathrm{min}$ \\
Nebulizer gas flow & $0.8 \mathrm{~L} / \mathrm{min}$ \\
Peristaltic pump flow rate & $2.5 \mathrm{~mL} / \mathrm{min}$ \\
RF power & $1300 \mathrm{watts}$ \\
Replicates & 2 \\
Delay time & $60 \mathrm{sec}$ \\
Spray chamber & Ryton Double Pass Scott type \\
Nebulizer & Gem Tip Cross Flow II \\
Injector & Alumina, 2.0 mm ID \\
Sample tubing & $0.76 \mathrm{~mm}$ ID \\
Drain tubing & $1.14 \mathrm{~mm}$ ID \\
\hline
\end{tabular}

\section{Statistical analysis of data}

Data on water quality parameters at various sites was statistically analyzed through one-way analysis of variance to compare the means for statistically significant differences. Post hoc analysis was carried out through Fisher's Least Significant Difference (LSD) test to identify the difference between pair of means. All statistical analysis was carried out using Minitab-17 software.

\section{Results and Discussion}

Freshwater ecosystems that provide multifarious services to the mankind have been subjected to substantial variations causing manipulation of ecological structure and processes [14]. Unique quality characteristics of each natural freshwater reservoir are regulated by multiple natural factors and anthropomorphic activities. Pollution load from the civilizations in the form of wastewater is the most critical anthropomorphic factor $[15,16]$. Preceding research on the surface water quality in Pakistan has revealed a parallel rise in aquatic pollution with increase in 
industrialization and urbanization [17, 18]. Devastating variation in physico-chemical parameters or addition of poisonous substances cause acute or sublethal toxic effects in the aquatic organisms and lead to altered community balance [19].

Results of the current water quality survey of river Ravi have revealed that addition of untreated municipal and industrial discharge is deteriorating its aquatic environment through dissolved oxygen depletion and higher toxic metals content. Table 4 shows water quality guidelines for propagation of fish and aquatic life as well as drinking and recreational uses [8, 20-22]. Physicochemical parameters and the heavy metals content of the river water as investigated in the present study are presented in Table 5 and Table 6, respectively along with analysis of variance.

Table 4. Guidelines for various water quality parameters.

\begin{tabular}{|l|c|c|c|c|c|c|c|c|c|c|}
\hline Water Quality Guidelines & $\begin{array}{c}\text { Temperature } \\
\left({ }^{\circ} \mathbf{C}\right)\end{array}$ & $\begin{array}{c}\text { DO } \\
(\mathbf{m g} / \mathbf{L})\end{array}$ & $\mathbf{p H}$ & $\begin{array}{c}\text { Conductivity } \\
(\mu \mathbf{\mu} / \mathbf{c m})\end{array}$ & $\begin{array}{c}\text { Turbidity } \\
(\mathbf{N T U})\end{array}$ & $\begin{array}{c}\mathbf{M n} \\
(\mu \mathbf{g} / \mathbf{L})\end{array}$ & $\begin{array}{c}\mathbf{N i} \\
(\mu \mathbf{g} / \mathbf{L})\end{array}$ & $\begin{array}{c}\mathbf{Z n} \\
(\mu \mathbf{g} / \mathbf{L})\end{array}$ & $\begin{array}{c}\mathbf{C d} \\
(\mu \mathrm{g} / \mathbf{L})\end{array}$ & $\begin{array}{c}\mathbf{P b} \\
(\mu \mathbf{g} / \mathbf{L})\end{array}$ \\
\hline For fish and aquatic life $^{(\mathrm{a})}$ & $\Delta \mathrm{T}<3$ than control & $>\mathbf{5}$ & $6.5-8.5$ & 1500 & - & 100.00 & 50.00 & 86.00 & $<2.00$ & 10.00 \\
\hline For recreational purposes $^{(\mathrm{b})}$ & $\Delta \mathrm{T}<3$ than control & 4 & $6.5-8.5$ & 1500 & - & - & - & 15000.00 & 10.00 & 10.00 \\
\hline Drinking water (Pakistan) $^{(\mathrm{c})}$ & - & - & $6.5-8.5$ & - & $<5 \mathrm{NTU}$ & $\leq 500.00$ & $\leq 20.00$ & 5000.00 & 10.00 & $\leq 50.00$ \\
\hline Drinking water (WHO) $^{(\mathrm{d})}$ & - & - & $6.5-8.5$ & - & $<5 \mathrm{NTU}$ & 500.00 & 20.00 & 3000.00 & 3.00 & 10.00 \\
\hline Drinking water (USEPA) $^{(\mathrm{e})}$ & - & - & $6.5-8.5$ & - & - & 50.00 & - & 5000.00 & 5.00 & 15.00 \\
\hline
\end{tabular}

a, b: [8], c:[20], d:[21], e:[22]

Table 5. Physico-Chemical parameters of river water at various sites (mean $(n=3) \pm S D)$.

\begin{tabular}{|c|c|c|c|c|c|}
\hline Site Code & $\begin{array}{c}\text { Temperature } \\
\left({ }^{\circ} \mathrm{C}\right)\end{array}$ & pH & $\begin{array}{c}\text { DO } \\
(\mathrm{mg} / \mathrm{L})\end{array}$ & Conductivity $(\mu \mathrm{S} / \mathrm{cm})$ & $\begin{array}{c}\text { Turbidity } \\
\text { (NTU) }\end{array}$ \\
\hline KNS & $16.6 \pm 0.10^{\mathrm{d}^{*}}$ & $8.20 \pm 0.05^{\mathrm{b}}$ & $7.30 \pm 0.12^{\mathrm{d}}$ & $329 \pm 3.06^{\mathrm{h}}$ & $1.78 \pm 0.02^{\mathrm{h}}$ \\
\hline KKN & $14.0 \pm 0.06^{\mathrm{i}}$ & $8.67 \pm 0.02^{\mathrm{c}}$ & $8.60 \pm 0.12^{\mathrm{a}}$ & $367 \pm 3.61^{\mathrm{f}}$ & $9.6 \pm 4.96^{\mathrm{f}}$ \\
\hline VK & $12.5 \pm 0.06^{\mathrm{j}}$ & $8.55 \pm 0.03^{\mathrm{a}}$ & $8.50 \pm 0.06^{\mathrm{b}}$ & $340 \pm 1.00^{\mathrm{g}}$ & $5.64 \pm 0.02^{\mathrm{g}}$ \\
\hline ORB1 & $14.0 \pm 0.00^{\mathrm{i}}$ & $7.93 \pm 0.05^{\mathrm{d}}$ & $7.80 \pm 0.06^{\mathrm{c}}$ & $385 \pm 0.58^{\mathrm{e}}$ & $13.6 \pm 0.35^{\mathrm{d}, \mathrm{e}}$ \\
\hline ORB2 & $14.2 \pm 0.06^{\mathrm{h}}$ & $7.72 \pm 0.04^{\mathrm{e}}$ & $5.30 \pm 0.06^{\mathrm{e}}$ & $533 \pm 3.06^{\mathrm{d}}$ & $41.0 \pm 0.25^{\mathrm{a}}$ \\
\hline VGR & $18.2 \pm 0.00^{\mathrm{b}}$ & $7.91 \pm 0.04^{\mathrm{d}}$ & $1.20 \pm 0.00^{\mathrm{g}}$ & $535 \pm 2.31^{\mathrm{d}}$ & $25.5 \pm 0.31^{\mathrm{b}}$ \\
\hline SPK & $20.5 \pm 0.10^{\mathrm{a}}$ & $7.77 \pm 0.04^{\mathrm{e}}$ & $1.30 \pm 0.12^{\mathrm{g}}$ & $534 \pm 2.52^{\mathrm{d}}$ & $16.0 \pm 0.20^{\mathrm{d}}$ \\
\hline VKPU & $15.8 \pm 0.00^{\mathrm{g}}$ & $7.42 \pm 0.02^{\mathrm{h}}$ & $2.20 \pm 0.06^{\mathrm{f}}$ & $639 \pm 1.00^{c}$ & $12.2 \pm 0.20^{\mathrm{e}}$ \\
\hline VKPD & $16.2 \pm 0.06^{\mathrm{e}}$ & $7.41 \pm 0.02^{\mathrm{h}}$ & $0.60 \pm 0.06^{\mathrm{h}}$ & $641 \pm 2.08^{\mathrm{c}}$ & $19.8 \pm 0.40^{\mathrm{c}}$ \\
\hline VNDS & $17.2 \pm 0.01^{\mathrm{c}}$ & $7.52 \pm 0.01^{\mathrm{g}}$ & $\mathrm{ND}^{\mathrm{i}}$ & $1072 \pm 1.53^{\mathrm{a}}$ & $24.5 \pm 0.36^{\mathrm{b}}$ \\
\hline BHW & $16.0 \pm 0.06^{\mathrm{f}}$ & $7.59 \pm 0.01^{\mathrm{f}}$ & $2.10 \pm 0.06^{\mathrm{f}}$ & $852 \pm 2.52^{\mathrm{b}}$ & $16.3 \pm 0.26^{\mathrm{d}}$ \\
\hline
\end{tabular}

ND: Not Detected; Means with similar superscripts in one column are statistically similar at P>0.05; When analyte was not detected (ND), its content was assumed to be $0.00 \mu \mathrm{g} / \mathrm{L}$ for post hoc analysis 
Table 6. Heavy metals content of river water at various sites (Mean $(n=3) \pm S D)$.

\begin{tabular}{|c|c|c|c|c|c|}
\hline Site Code & $\begin{array}{c}\text { Mn } \\
(\mu \mathrm{g} / \mathrm{L})\end{array}$ & $\begin{array}{c}\mathbf{Z n} \\
(\mu \mathrm{g} / \mathrm{L})\end{array}$ & $\begin{array}{c}\text { Cd } \\
(\mu \mathrm{g} / \mathrm{L})\end{array}$ & $\begin{array}{c}\mathrm{Ni} \\
(\mu \mathrm{g} / \mathrm{L})\end{array}$ & $\begin{array}{c}\text { Pb } \\
(\mu \mathrm{g} / \mathrm{L})\end{array}$ \\
\hline KNS & $20.00 \pm 0.0^{\mathrm{e}}$ & $\mathrm{ND}^{\mathrm{d}}$ & $\mathrm{ND}^{\mathrm{c}}$ & $\mathrm{ND}^{\mathrm{b}}$ & $\mathrm{ND}^{\mathrm{g}}$ \\
\hline KKN & $N D^{f}$ & $\mathrm{ND}^{\mathrm{d}}$ & $\mathrm{ND}^{\mathrm{c}}$ & $\mathrm{ND}^{\mathrm{b}}$ & $34.0 \pm 10.0^{\mathrm{d}, \mathrm{e}}$ \\
\hline VK & $N D^{f}$ & $\mathrm{ND}^{\mathrm{d}}$ & $\mathrm{ND}^{\mathrm{c}}$ & $\mathrm{ND}^{\mathrm{b}}$ & $20.0 \pm 4.0^{\mathrm{f}}$ \\
\hline ORB1 & $43.00 \pm 10.0^{\mathrm{d}}$ & $\mathrm{ND}^{\mathrm{d}}$ & $\mathrm{ND}^{\mathrm{c}}$ & $\mathrm{ND}^{\mathrm{b}}$ & $31.0 \pm 10.0^{\mathrm{e}, \mathrm{f}}$ \\
\hline ORB2 & $20 \pm 10.0^{\mathrm{e}}$ & $\mathrm{ND}^{\mathrm{d}}$ & $\mathrm{ND}^{\mathrm{c}}$ & $\mathrm{ND}^{\mathrm{b}}$ & $40.0 \pm 1.0^{\mathrm{d}, \mathrm{e}}$ \\
\hline VGR & $70.00 \pm 10.0^{\mathrm{c}}$ & $60.00 \pm 30.0^{\mathrm{d}}$ & $\mathrm{ND}^{\mathrm{a}, \mathrm{b}}$ & $\mathrm{ND}^{\mathrm{b}}$ & $43.0 \pm 10.0^{, \mathrm{d}, \mathrm{e}}$ \\
\hline SPK & $73.00 \pm 10.0^{\mathrm{c}}$ & $40.00 \pm 10.0^{\mathrm{d}}$ & $\mathrm{ND}^{\mathrm{b}}$ & $\mathrm{ND}^{\mathrm{b}}$ & $48.0 \pm 5.0^{\mathrm{c}, \mathrm{d}}$ \\
\hline VKPU & $12.00 \pm 10.0^{\mathrm{b}}$ & $70.00 \pm 40.0^{\mathrm{b}}$ & $0.60 \pm 0.20^{\mathrm{a}}$ & $\mathrm{ND}^{\mathrm{b}}$ & $50.0 \pm 6.0^{, \mathrm{c}}$ \\
\hline VKPD & $120.00 \pm 0.0^{\mathrm{b}}$ & $\mathrm{ND}^{\mathrm{a}}$ & $2.0 \pm 0.00^{\mathrm{c}}$ & $20.00 \pm 0.00^{\mathrm{a}}$ & $60.0 \pm 20.0^{\mathrm{a}, \mathrm{b}}$ \\
\hline VNDS & $190.00 \pm 20.0^{\mathrm{a}}$ & $\mathrm{ND}^{\mathrm{b}}$ & $0.60 \pm 0.20^{\mathrm{c}}$ & $\mathrm{ND}^{\mathrm{b}}$ & $72.0 \pm 1.0^{\mathrm{a}}$ \\
\hline BHW & $120.00 \pm 10.0^{\mathrm{b}}$ & $\mathrm{ND}^{\mathrm{c}}$ & $0.40 \pm 0.30^{\mathrm{c}}$ & $\mathrm{ND}^{\mathrm{b}}$ & $44.00 \pm 5.0^{\mathrm{c}, \mathrm{d}, \mathrm{e}}$ \\
\hline
\end{tabular}

\section{Physico-chemical analysis}

River water was analyzed for its physicochemical characteristics viz. temperature, dissolved oxygen (DO), pH, conductivity and turbidity. Oneway analysis of variance indicated significant differences among the analyzed water parameters at various sampling sites $(\mathrm{P}<0.05)$. Water temperature ranged from $12.5{ }^{\circ} \mathrm{C} \pm 0.06{ }^{\circ} \mathrm{C}$ (at VK) to $20.5{ }^{\circ} \mathrm{C} \pm 0.10{ }^{\circ} \mathrm{C}$ (at SPK) as measured during the sampling duration of two months. Water quality guidelines for aquatic organisms [8] suggest a temperature change of less than $3{ }^{\circ} \mathrm{C}$ in either direction as compared to an upstream control point. Temperature of the upstream control point (KNS) was found to be $16.6{ }^{\circ} \mathrm{C} \pm 0.10{ }^{\circ} \mathrm{C}$. The greater temperature variation, however, can be attributed to the different sampling times and days.

One of the most critical water quality parameter for aquatic life, was found to be higher than the recommended limit of $>5 \mathrm{mg} / \mathrm{L}$ for aquatic life and $\geq 4 \mathrm{mg} / \mathrm{L}$ for recreational purposes from KNS up to ORB1 and ORB2. However, DO content was below these proposed limits at all the other sites. A decrease of about $77 \%$ in water DO level was observed from ORB2 to VGR. DO content was found to be less than $2.2 \mathrm{mg} / \mathrm{L}$ at all sites from VGR up to BHW and at VNDS, it was not detected. Likewise, oxygen deficiency of the water increased along the length of the river (Fig. 2). River water was found to be deficient in oxygen at all sampling sites with lowest oxygen deficiency $(1.72 \mathrm{mg} / \mathrm{L})$ found at $\mathrm{KKN}$ and highest $(9.6 \mathrm{mg} / \mathrm{L})$ at VNDS. Microbial heterotrophic utilization of non-conservative organic loads leads to DO depletion in the receiving water bodies. The acceleration of this utilization at higher temperature as well as lower DO saturation level of warmwater make summer the critical period for the aquatic biota [23]. A minimum of $5 \mathrm{mg} / \mathrm{L}$ DO must be present in the water body to sustain healthy growth of fish and other aquatic organisms $[8,12]$. DO content of less than $5 \mathrm{mg} / \mathrm{L}$ may initiate a course of physiological reactions in fish as it tries to compensate for low oxygen availability. These compensatory responses can help the healthy fish to survive for a certain period of time, after which, low oxygen concentrations can cause fish mortality [12]. Moreover, low DO stressor can also lead to disease outbreak in fish population [24]. According to the present study, the pollution load received by river Ravi has lowered its DO level to drastic levels at downstream sites of discharge points of wastewater drains. River water quality has been deteriorated to such an extent at Village Nano Dogar (situated at downstream vicinity of discharge points of Hudiara Drain and Deg Drain) that DO remained undetected at this site. DO of 
less than $2.2 \mathrm{mg} / \mathrm{L}$ from Village Gopi Roy up to Balloki Headworks has indicated that the river water is not suitable for survival of fish and sensitive aquatic populations at these sites. DO contents of river water detected in present study are lower than those recorded in earlier investigations [25, 26]. Shakir et al. [25] found DO content in river water to be $3.80 \mathrm{mg} / \mathrm{L}$ and 4.13 $\mathrm{mg} / \mathrm{L}$ at Sunder and Balloki Headworks respectively. Rauf and coworkers [26] reported mean annual DO content to be $4.56 \pm 1.56 \mathrm{mg} / \mathrm{L}$ and $6.79 \pm 1.81 \mathrm{mg} / \mathrm{L}$ in River Ravi at Sunder and Balloki Headworks, respectively.

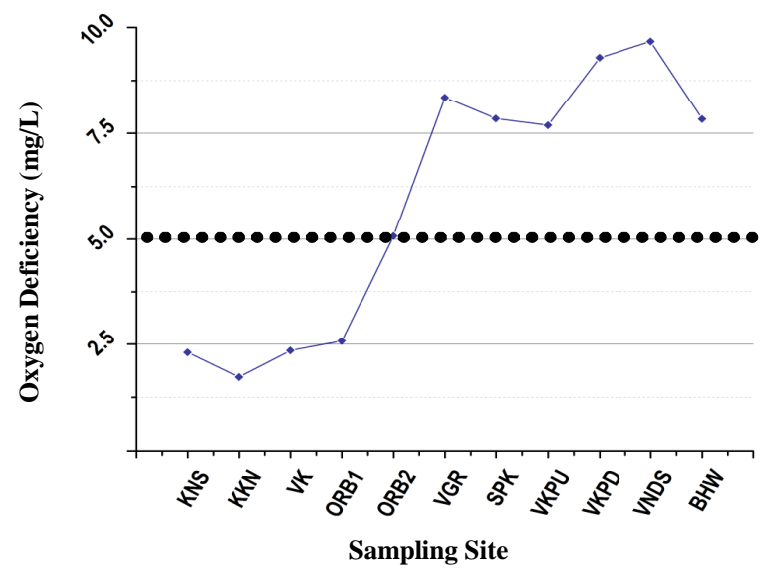

Figure 2. Oxygen deficiency in river Ravi at various sites

$\mathrm{pH}$ of the river water ranged from $7.41 \pm$ 0.02 (VKPD) to $8.61 \pm 0.02(\mathrm{KKN})$. Water quality guidelines for drinking water, for propagation of fish \& aquatic life and recreational purposes (Table 4) suggest water $\mathrm{pH}$ of 6.50-8.50. Maximum water $\mathrm{pH}$ of $8.61 \pm 0.02$ detected at KKN was slightly higher than the recommended range. However, this increase cannot be attributed to pollution load as no point source of pollution can be identified at these sites. Moreover, suitable $\mathrm{pH}$ limit of 6.5-9 has been reported by Boyd [13] for freshwater fish propagation. $\mathrm{pH}$ at all the polluted sites of the river was less than 8.0 and ranged from $7.41 \pm 0.02$ at VKPD to $7.91 \pm 0.04$ at ORB1. At Village Nano Dogar Sunder and Balloki Headworks, $\mathrm{pH}$ was found to be $7.52 \pm 0.01$ and $7.59 \pm 0.01$ respectively. These results are in agreement with those of Rauf et al. [26] who reported mean annual value for water $\mathrm{pH}$ to be
$7.56 \pm 0.45$ and $7.63 \pm 0.44$ at Sunder and Balloki Headworks, respectively.

Conductivity of the river water ranged from $329 \pm 3.09 \mu \mathrm{S} / \mathrm{cm}$ (at KNS) to $1072 \pm 1.53$ $\mu \mathrm{S} / \mathrm{cm}$ (at VNDS) and remained within the proposed limit of $<1500 \mu \mathrm{S} / \mathrm{cm}$ for freshwater aquatic life and recreational use [8] at all sites. Water conductivity gradually increased along the length of the river from KNS up to VKPD. However, an abrupt increase (67\%) in water conductivity was found as river flowed from VKPD $(641 \pm 2.08 \mu \mathrm{S} / \mathrm{cm})$ to $\operatorname{VNDS}(1072 \pm 1.53$ $\mu \mathrm{S} / \mathrm{cm})$. Sudden change in water conductivity indicates addition of polluted water in the river that leads to higher ionic concentration. At BHW, water conductivity decreased to $852 \pm 2.52 \mu \mathrm{S} / \mathrm{cm}$. Recorded conductivity values are higher than those reported by Mahmood and co-workers [27] who found mean annual river water conductivity to be $455.14 \pm 77.37 \mu \mathrm{S} / \mathrm{cm}$ and $322.80 \pm 68.29 \mu \mathrm{S} / \mathrm{cm}$ at Sunder and Balloki Headworks, respectively. Turbidity of the river water was found to vary from $1.78 \pm 0.02 \mathrm{NTU}$ (at KNS) to $41.0 \pm 0.25 \mathrm{NTU}$ (at ORB2). Water turbidity at all sites was higher than the maximum recommended limit of $5 \mathrm{NTU}$ for drinking water except at KNS (Table 5). However, water turbidity was lower than $50 \mathrm{NTU}$ at all sites that is maximum permissible turbidity value suggested by Borok [28] for warmwater aquatic life.

\section{Heavy metals analysis}

Significant differences in heavy metals contents were found at various sampling sites $(\mathrm{P}<0.05)$. Manganese $(\mathrm{mn})$ was detected in the river water at all sites except at $\mathrm{KKN}$ and $\mathrm{VK}$. Maximum permissible limit of $\mathrm{Mn}$ suitable for propagation of aquatic life is proposed to be 100.0 $\mu \mathrm{g} / \mathrm{L}$ (Table 4). Detected Mn content in river water ranged from $20.0 \pm 0.0 \mu \mathrm{g} / \mathrm{L}$ (at KNS) to $190.0 \pm$ $20.0 \mu \mathrm{g} / \mathrm{L}$ (at VNDS). The Mn concentration $(120.0 \pm 0.0 \mu \mathrm{g} / \mathrm{L})$ higher than the permissible limit was found at VKPD that increased to $190.0 \pm$ $20.0 \mu \mathrm{g} / \mathrm{L}$ at VNDS exhibiting about $58 \%$ increase in Mn content. At VGR, SPK, VKPD, VNDS and BHW, Mn content exceeded the safe limit of 50.0 $\mu \mathrm{g} / \mathrm{L}$ proposed by USEPA for drinking water. Shakir et al. [18] have also reported increasing 
metals content in river Ravi water as it flows through Lahore city. Authors reported 264\% and $502 \%$ increase in Mn content in river water at Shahdara and Sunder than at Lahore Siphon. In present study, Nickel remained undetected at all sites except at VNDS. Its content $(20.0 \pm 0.0 \mu \mathrm{g} / \mathrm{L})$ at this site was less than the maximum permitted limit of $50.0 \mu \mathrm{g} / \mathrm{L}$ for aquatic life and equal to maximum allowable limit of $20.0 \mu \mathrm{g} / \mathrm{L}$ set for drinking water by WHO as well as Pakistan EPA. Cadmium (Cd) was either not detected or remained below the permissible limit of $2.0 \mu \mathrm{g} / \mathrm{L}$ for propagation of aquatic life at all sampling sites except at VKPD. The Cd content exhibited an abrupt increase of about $233 \%$ from VKPU $(0.60 \pm$ $0.2 \mu \mathrm{g} / \mathrm{L})$ to VKPD $(2.0 \pm 0.0 \mu \mathrm{g} / \mathrm{L})$. The results are in agreement with those of Shakir et al. [18] who reported $167 \%$ and $467 \%$ increase in Cd content as iver Ravi flowed from Lahore Siphon to Shahdara and Sunder respectively. Rauf and coworkers [26] have reported mean annual $\mathrm{Cd}$ content to be $590 \pm 430 \mu \mathrm{g} / \mathrm{L}$ in river Ravi water at Sunder.

Zinc (Zn) was detected only at three sites (VGR, SPK and VKPU) in current study where its concentration remained below the maximum permitted limit for aquatic life, recreational uses [8] and drinking water [21, 22] (Table 4). Tabinda and co-workers [29] reported $\mathrm{Zn}$ content of 480 $\mu \mathrm{g} / \mathrm{L}$ in river water at Balloki Headworks that was higher than the limit proposed for fish and aquatic life [8]. Lead $(\mathrm{Pb})$ was detected in river water at all sampling sites except at KNS. Its concentration varied from $20.0 \pm 4.0 \mu \mathrm{g} / \mathrm{L}$ (at VK) to $72.0 \pm 1.0$ $\mu \mathrm{g} / \mathrm{L}$ (at VNDS). The Pb content of $34.00 \pm 10.00$ $\mu \mathrm{g} / \mathrm{L}$ at $\mathrm{KKN}$ decreased to $20.00 \pm 4.00 \mu \mathrm{g} / \mathrm{L}$ at VK $(41 \%$ decrease). Increase in water $\mathrm{Pb}$ content (260\%) was found from VK up to VNDS. A decrease of about 39\% was observed in $\mathrm{Pb}$ content as the river flowed from VNDS to BHW. Detected content of $\mathrm{Pb}$ at all the sites was higher than the proposed safe limits $(10 \mu \mathrm{g} / \mathrm{L})$ for fish \& aquatic life and recreational purposes [8]. Lead concentration in river water exceeded permissible limits for drinking water set by WHO [21] and USEPA [22] at all sites and those proposed by Pakistan EPA [20] at VKHP and VNDS (Table 4).
According to the present study, river Ravi is polluted with heavy metals especially $\mathrm{Pb}$, and $\mathrm{Mn}$ whose contents higher than safe limits proposed for propagation of fish and aquatic life have been detected at a number of polluted sites. Heavy metals concentration in river water decreased in the following order: $\mathrm{Mn}>\mathrm{Pb}>\mathrm{Zn}>$ $\mathrm{Ni}>\mathrm{Cd}$. Earlier studies on water quality of river Ravi have also revealed that pollution load is deteriorating aquatic ecosystem of the river [18, 26, 29, 30]. Shakir et al. [18] reported that heavy metals content in river water at Shahdara and Sunder exceeded the maximum permissible limits set by water quality guidelines of WHO [21] and USEPA [22]. According to their study, order of metal content in river water was; $\mathrm{Fe}>\mathrm{Zn}>\mathrm{Mn}>\mathrm{Cr}>\mathrm{Cu}>\mathrm{Ni}>\mathrm{Hg}>\mathrm{Pb}>\mathrm{Cd}$. Rauf et al. [26] also found higher heavy metals content (Co, $\mathrm{Cr}, \mathrm{Cu}, \mathrm{Cd}$ ) in river Ravi water than safe limits for drinking water proposed by WHO [21] and emphasized the regular monitoring of toxic metals content in river water. In the present study, decreasing trends in metals concentration were observed at Balloki Headworks that can be attributed to the dilution effect produced by relatively unpolluted water of Qadirabad-Balloki Link Canal that joins the river about $15 \mathrm{~km}$ ahead of Balloki Headworks. Similar results have been found by Rauf et al. [26], Shakir et al. [18] and Javed \& Hayat [31] who have also reported decreased metal concentration in river water at Balloki Headworks. Metals concentrations in river water detected in the present study were lower than that determined by other investigators at different time periods $[18,29-31]$. This difference can be attributed to the temporal variations in the metallic toxicants entering the riverine environment and their possible adsorption at the river sediments. Javed \& Mahmood [30] also observed that heavy metals content in river Ravi water varied throughout the year and concluded that this variation was caused by fluctuations in discharge of polluted sewage and industrial wastewater into the river. A comparison of heavy metals content in river water recorded in the present study and reported in earlier investigations at Balloki Headworks is presented in Table 7. 
Table 7. Comparison of heavy metal content $(\mu \mathrm{g} / \mathrm{L})$ in river Ravi water at Balloki Headworks.

\begin{tabular}{c|c|c|c|c|c}
\hline \multicolumn{5}{c|}{ Metals content } & \multirow{2}{*}{ Reference } \\
\cline { 1 - 4 } $\begin{array}{c}\mathbf{P b} \\
(\boldsymbol{\mu g} / \mathbf{L})\end{array}$ & $\begin{array}{c}\mathbf{C d} \\
(\boldsymbol{\mu g} / \mathbf{L})\end{array}$ & $\begin{array}{c}\mathbf{N i} \\
(\boldsymbol{\mu g} / \mathbf{L})\end{array}$ & $\begin{array}{c}\mathbf{M n} \\
(\boldsymbol{\mu g} / \mathbf{L})\end{array}$ & $\begin{array}{c}\mathbf{Z n} \\
(\boldsymbol{\mu g} / \mathbf{L})\end{array}$ & \\
\hline 44.00 & 0.40 & $\mathrm{ND}$ & 120.00 & $\mathrm{ND}$ & $\begin{array}{c}\text { Present } \\
\text { Study }\end{array}$ \\
1340.0 & 130.0 & 1540.0 & 6430.0 & 29120.0 & {$[18]$} \\
- & - & 40.00 & - & 172.0 & {$[29]$} \\
370.00 & - & 560.0 & 940.0 & 630.0 & {$[30]$} \\
\hline ND: Not detected
\end{tabular}

\section{Conclusion}

Present study has revealed that addition of untreated effluents in River Ravi is causing deterioration of its aquatic ecosystem particularly at Village Khudpur, Village Nano Dogar and Balloki Headworks. The river's water seems not to be suitable for drinking purposes due to its high turbidity and lead content. River water is not able to support fish and aquatic biota at polluted sites due to its extremely low dissolved oxygen level. Low dissolved oxygen content cause direct lethal and sublethal effects in aquatic organisms and can also act as a stressor for fish and other aquatic animals increasing the toxicity of pollutants. In addition, low dissolved oxygen concentration can lead to highly polluted aquatic environment due to accumulation of toxic substances [12]. Persistently low DO content can convert the river to an unstable and worthless ecosystem with low biodiversity.

There is a negative correlation between water $\mathrm{pH}$ and heavy metals solubility in river water and latter increases with a decrease in $\mathrm{pH}$ [31]. In the current study, hydrogen ion concentration remained within the proposed limits for aquatic life, however, decreasing $\mathrm{pH}$ observed along the river stretch can lead to higher metals solubility in the river water. Content of certain heavy metals as detected in present study raises questions about healthy growth and physiological conditions of fish and other aquatic life in the river and also marks an alarming situation for the human population. Aquatic organisms can bioconcenterate the heavy metals up to $1,000,000$ times their content detected in water column [32]. Fish, being at top of aquatic food webs, can become victim of bioaccumulation and biomagnification of toxic metals. Bioaccumulation of heavy metals in fish depend upon a number of abiotic and biotic factors $[33,34]$. Bioconcentration of toxic heavy metals in edible fish species pose a significant threat for humans as consumption of contaminated fish can expose human beings to harmful effects of these toxicants.

On the basis of current pollution status of river Ravi, following recommendations have been proposed to restore the ecosystem and prevent its further degradation.

1. Establishment of wastewater treatment plants to treat the municipal and industrial effluents has become inevitable to control further degradation of receiving water reservoirs. Treated water discharged in the inland water bodies must meet the National Environmental Quality Standards (NEQS).

2. Stringent laws should be implemented to control the presence of toxic substances in industrial effluents. Industrial units that volunteer to install treatment plants at their facilities should be facilitated by the tax rebate or relevant financial privileges such as provision of required technology at low cost rates.

3. Chemical analysis of water in wastewater carrying drains should be carried out as a regular activity to monitor level of toxins and recommend mitigation measures. Formulation of a database based on type and concentration of identified pollutants as determined in periodic analysis will aid in design and operation of treatment plants.

4. Extensive analysis of river water quality should be carried out at regular intervals along the entire length of the river to reveal the pollution status and health of the aquatic ecosystem and adopt appropriate preventive measure. Preconcenteration of toxic heavy metals in water prior to analysis [35] can be employed for detection of very low metals content to determine the potential hazards posed to river ecosystem.

5. Seasonal variation in heavy metals content of river Ravi should be determined to gain further insight about the level of ecosystem deterioration. 
6. Heavy metals contents in the body organs of edible fish fauna should be examined regularly. The collected data will serve as bioindicator of river pollution and help to explore possible threats posed to human health through consumption of contaminated fish.

7. Awareness programmes should be initiated to educate public about polluted state of our aquatic ecosystems and its role towards aquatic pollution control.

\section{Acknowledgment}

Authors are thankful to Drainage Directorate, WASA, Lahore and Programme Monitoring and Implementation Unit, Irrigation Department, Punjab for providing the useful information during the study.

\section{References}

1. C. J. Vorosmarty, P. B. McIntyre, M. O. Gessner, D. Dudgeon, A. Prusevich, P. Green, S. Glidden, S. E. Bunn, C. A. Sullivan and C. R. Liermann, Nature, 467 (2010) 555. doi: 10.1038/nature09440

2. E. B. Welch, and T. Lindell, Ecological Effects of Wastewater: Applied Limnology and Pollutant Effects (E \& FN Spon, London) 2/e (2004) 436. https://trove.nla.gov.au/version/45109532

3. G. T. Miller, and S. Spoolman, Living in the Environment: Principles, Connections, and Solutions (Cengage Learning, Stamford) 17/e (2012) 832.

http://www.mtcarmelacademy.net/uploads/1/ 1/7/5/11752808/living in the environment 16th edition - miller.pdf

4. H. G. Peterson, F. P. Healey and R. Wagemann, Can. J. Fish. Aquat. Sci., 41 (1984) 974. doi: 10.1139/f84-111.

5. M. M. Zeitoun and E.-S. E. Mehana, Global Veterinaria, 12 (2014) 219. doi:10.5829/idosi.gv.2014.12.02.82219.

6. J. I. Spicer and R. E. Weber, Comparative Biochemistry and Physiology Part C: Comparative Pharmacol., 100 (1991) 339.
doi:10.1016/0742-8413(91)90005-E.

7. P. B. Tchounwou, C. G. Yedjou, A. K. Patlolla and D. J. Sutton, In: Molecular, Clinical and Environmental Toxicology, Vol. 3: Environmental Toxicology (A. Luch, Ed) Springer, Basel (2012) 132.

8. WWF, National water classification criteria and irrigation water quality guidelines for Pakistan. Freshwater and Toxics Programme, World Wide Fund-For Nature, Lahore (2007). Retrived from http://mocc.gov.pk/moclc/userfiles1/file/MO C/National\%20Environment\%20Quality\%20 Standards/National $\% 20$ Surface $\% 20$ Water $\%$ 20Classification\%20Criteria.pdf

9. MOE-PAK, State of the Environment Report 2005 (Draft). Pakistan: Ministry of Environment, Government of Pakistan, Islamabad (2005). Retrieved from http://environment.gov.pk/PUB PDF/StateE R2005/TitleTOC.pdf

10. M. Saeed and A. Bahzad, Pak. J. Water Resour., 10 (2006) 43.

http://agris.fao.org/agrissearch/search.do?recordID=PK2007001006

11. N. Ejaz, H. N. Hashmi and A. R. Ghumman, Mehran Uni. Res. J. Eng. Technol., 30 (2011) 383.

http://oaji.net/articles/2015/2712-

1451164340.pdf

12. C. E. Boyd, Water Quality: An Introduction (Kluwer Academic Publishers, New York) 2/e (2015) 357. https://www.springer.com/gb/book/9783319 174457

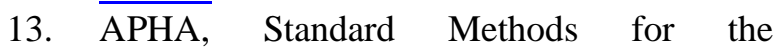
Examination of Water and Wastewater (American Public Health Association, Washington) 22/e (2012) 1496. https://www.mwa.co.th/download/file uploa d/SMWW 1000-3000.pdf

14. S. R. Carpenter, E. H. Stanley and M. J. Vander Zanden, Annu. Rev. Environ. Resour., 36 (2011) 75.

doi:10.1146/annurev-environ-021810094524.

15. K. M. Vigil, Clean Water: An Introduction to Water Quality and Water Pollution Control (Oregon State University Press, Corvallis) 2/e (2003) 181. 
http://www.waterbeacon.org/s/Clean-Water-

An-Introduction-to-Water-Quality-and-

Pollution-Control.pdf

16. M. Tuzen and M. Soylak, Pol. J. Environ. Stud., 15 (2006) 915.

https://pdfs.semanticscholar.org/c2e0/4d308 6a67ba2b67ac95375ba0b6d66849604.pdf

17. Z. S. Mirza, M. S. Nadeem, M. Beg, A. Sulehria and S. I. Shah, Biologia, 58 (2012) 31.

http://www.gcu.edu.pk/Publications/Biologi a/Vol58_No1\&2_2012.pdf

18. H. A. Shakir, J. I. Qazi and A. S. Chaudhry, Environ. Monit. Assess., 185 (2013) 9705. doi: 10.1007/s 10661-013-3284-2.

19. J. M. Hellawell, Biological Indicators of Freshwater Pollution and Environmental Management (Elsevier Science Publishers Ltd., London) 1/e (1986) 546. https://doi.org/10.1007/978-94-009-4315$\underline{53}$

20. NSDWQ, National Standards for Drinking Water Quality (Pakistan Environmental Protection Agency, Islamabad) (2008). Retrieved from http://waterinfo.net.pk/sites/default/files/kno wledge/NSDWQ\%20Drinking\%20Water\%2 0\%202007.pdf.

21. WHO, Guidelines for Drinking Water Quality, ${ }^{\text {rd }}$ Ed. (World Health Organization, Geneva) (2004). Retrieved from http://apps.who.int/iris/bitstream/10665/4285 2/1/9241546387.pdf?ua=1

22. USEPA, National Primary Drinking Water Regulations. (EPA 816-F-09-004). (United States Environmental Protection Agency., Washington) (2009). https://www.nrc.gov/docs/ML1307/ML1307 8A040.pdf

23. A. V. Kneese, Water Pollution: Economic Aspects and Research Needs (Routledge, Abingdon, Oxon; New York) 1/e (2015) 124.https://www.amazon.com/Water-

Pollution-Economics-Research$\underline{\text { Routledge/dp/1138935654 }}$

24. S. Snieszko, J. Fish Biol., 6 (1974) 197. doi: 10.1111/j.1095-8649.1974.tb04537.x.

25. A. Shakir, A. S. Chaudhry and J. I. Qazi, Environ. Monit. Assess., 185 (2013) 2833. doi: 10.1007/s10661-012-2753-3.
26. A. Rauf, M. Javed, G. Jabeen, A. Javid and S. Makhdoom, J. Biodiv. Environ. Sci., 6 (2015) 141.

http://innspubjbes.blogspot.com/2015/05/con centration-of-heavy-metals-in-water.html

27. G. Mahmood, M. Javed and M. Hassan, Pak. J. Biol. Sci., 3 (2000) 1962.

http://www.docsdrive.com/pdfs/ansinet/pjbs/ 2003/1027-1029.pdf

28. Borok, A., Oregon Department of Environmental Quality (DEQ) Portland (2010). Retrieved from

http://www.deq.state.or.us/wq/standards/doc s/Turbidity/10-WQ-022.pdf

29. A. Tabinda, S. Bashir, A. Yasar and M. Hussain, J. Animal Plant Sci., 23 (2013) 76 http://www.thejaps.org.pk/docs/v-231/13.pdf

30. M. Javed and G. Mahmood, Pak. J. Agric. Sci., 38 (2001) 37.

https://www.pakjas.com.pk/papers/634.pdf

31. M. Javed and S. Hayat, Pak. J. Agric. Sci., 36 (1999) 81.

https://www.pakjas.com.pk/papers/708.pdf

32. USEPA, National Study of Chemical Residues in Fish. Volume I (EPA 823-R-92008a) (United States Environmental Protection Agency., Washington) (1992a).

33. D. Mendil, Z. Demirci, M. Tuzen and M. Soylak, Food Chem. Toxicol., 48 (2010) 865.

doi: 10.1016/j.fct.2009.12.023.

34. A. Jakimska, P. Konieczka, K. Skóra and J. Namieśnik, Pol. J. Environ. Stud., 20 (2011) 1127.

https://pdfs.semanticscholar.org/bb5a/8cb0f9 beb93f56b2633ffccbf36966444ef1.pdf

35. L. Elci, M. Soylak and M. Dogan, Fresenius J. Anal. Chem., 342 (1992) 175. doi: 10.1007/BF00321717. 